Boston University School of Law

Scholarly Commons at Boston University School of Law

Faculty Scholarship

1996

The Promised End: Constitutional Aspects of Physician-Assisted

Suicide

George J. Annas

Follow this and additional works at: https://scholarship.law.bu.edu/faculty_scholarship

Part of the Health Law and Policy Commons 
Legal Issues in Medicine

\section{The Promised End - Constitutional Aspects of Physician-Assisted Suicide}

\author{
George J. Annas, J.D., M.P.H.
}

$\mathrm{T}$ HE debate over physician-assisted suicide has dramatically shifted to a discussion of constitutional issues. This spring, within a month of each other, U.S. Circuit Courts of Appeals on both coasts ruled that state prohibitions of assisted suicide are unconstitutional when applied to physicians who prescribe lethal medication for terminally ill, competent adults who wish to end their lives. ${ }^{1,2}$ The Ninth Circuit includes Alaska, Arizona, California, Hawaii, Idaho, Montana, Nevada, Oregon, and Washington, and the Second Circuit includes New York, Connecticut, and Vermont. Both courts reached the same conclusion but for different legal reasons.

In the Ninth Circuit, four physicians and three patients (one dying of AIDS, one of cancer, and another of emphysema) challenged a Washington law that prohibits aiding another person in committing suicide. In the Second Circuit, three physicians and three patients (two dying of AIDS and one of cancer) challenged New York laws that prohibit aiding another person in committing or attempting suicide. None of these patients were currently suicidal, but all wanted lethal drugs that they could take if their suffering became unbearable. All the physicians said that they felt unable to comply with the requests because of the laws against assisting suicide (there are no laws against committing suicide). Both cases present the same two issues: Is there a constitutional right to the assistance of a physician in committing suicide? And if so, does the state nonetheless have a sufficient interest to prohibit the exercise of this right?

\section{THE OPINION OF THE NINTH CIRCUIT COURT}

The Ninth Circuit Court adopted the term "physician-assisted suicide" to describe "the prescription of life-ending medication for use by terminally ill, competent adult patients who wish to hasten their deaths" but was not happy with it, saying, "We have serious doubts that the terms 'suicide' and 'assisted suicide' are appropriate legal descriptions of the specific conduct at issue here." Instead of simply ruling that the assisted-suicide laws do not apply to the prescriptions of potentially lethal drugs, the court's ambitious eight-to-three opinion, written by Judge
Stephen Reinhardt, relied on a substantive due-process approach (based on the due-process clause of the 14th Amendment) to create a new constitutional right: the right to determine "the time and manner of one's own death."

This new right is broadly worded, but the court ruled that only a narrow category of patients may lawfully exercise it: competent, terminally ill adults who have "lived nearly a full measure" of life and who want to die with dignity. ${ }^{1}$ For such patients, "wracked by pain and deprived of all pleasure, a state-enforced prohibition on hastening their deaths condemns them to unrelieved misery or torture." Surely, the court concluded, choosing "whether to endure or avoid such an existence" is a liberty every bit as vital as that involved in deciding whether or not to proceed with a pregnancy. ${ }^{1}$ In the courts' words, "Like the decision of whether or not to have an abortion, the decision how and when to die is one of 'the most intimate and personal choices a person may make in a lifetime,' a choice 'central to personal dignity and autonomy.'"',3

The other analogy the Ninth Circuit Court relied on was the removal of feeding tubes. A majority of the U.S. Supreme Court had agreed that there was a liberty interest in "refusing unwanted medical treatment" in the case of Nancy Cruzan, a young woman in a persistent vegetative state whose family sought to have a feeding tube discontinued on her behalf. ${ }^{4}$ Because Nancy Cruzan would die without a feeding tube, the Ninth Circuit Court characterized the decision in the Cruzan case as having "necessarily recognize[d] a liberty interest in hastening one's own death," thus permitting "suicide by starvation." The court recognized that "as part of the tradition of administering comfort care, doctors have been supplying the causal agent of patients' deaths for decades"' and understood that physicians have justified this prescribing pattern on the basis of the "double effect - reduce the patient's pain and hasten [his or her] death."1 But the court rejected the double-effect rationale, saying, "We see little, if any, difference for constitutional or ethical purposes between providing medication with a double effect and providing medication with a single effect . . . [or] between a doctor's pulling the plug on a respirator and ... prescribing drugs which will permit a terminally ill patient to end [his or her] own life."1

After this new constitutional right is defined, the only remaining question is whether the state has a sufficient interest to prohibit its exercise. The court concluded that it does not: "When patients are no longer able to pursue liberty or happiness and do not wish to pursue life, the state's interest in forcing them to remain alive is clearly less [than] compelling." The court did, however, call on states to regulate the practice, suggesting procedural safeguards 
- such as witnesses, waiting periods, second medical opinions, psychological examinations, and reporting procedures - to help avoid "abuse."

\section{THE OPINION OF THE SECOND CIRCUIT COURT}

One month later, in April, the Second Circuit Court summarily rejected the Ninth Circuit Court's entire substantive due-process analysis as a defensible way to discover a new constitutional right, concluding simply, "The right to assisted suicide finds no cognizable basis in the Constitution's language or design, even in the very limited cases of those competent persons who, in the final stages of terminal illness, seek the right to hasten death." 2 But the Second Circuit Court nonetheless did find a new constitutional right underlying a doctor's lethal prescription, based on the equal-protection clause (rather than the due-process clause) of the 14th Amendment. The equal-protection clause requires states to treat people who are similarly situated in a similar manner. Although this is superficially a different constitutional approach from that of the Ninth Circuit Court, the Second Circuit Court also had to discover a new constitutional right before it could conclude that the right was being protected unequally by the state.

The Second Circuit Court did this by making two related assertions: the right to refuse treatment is the same as the right to "hasten death," and there is no distinction between a person who is dependent on life-support equipment and one who is not. Both assertions are problematic. As to the first, the court argued that New York treats similarly situated people unequally because its law permits people "in the final stages of terminal illness who are on life support systems . . . to hasten their deaths by directing the removal of such systems," but those not receiving life support cannot hasten their deaths "by self-administering prescription drugs." ${ }^{2}$ The primary cases cited for this proposition are Cruzan ${ }^{4}$ and Eichner, ${ }^{5}$ even though neither of the two patients involved, who were both in persistent vegetative states, was terminally ill, and neither had expressed any desire to commit suicide. The patient in the Eichner case, Brother Joseph Fox, was an elderly Catholic brother of the Society of Mary who had said to his friend, Father Phillip Eichner, before hernia surgery, "If I wind up like Karen Quinlan, pull the plug." Since suicide is a mortal sin in the Catholic Church, it is likely that Brother Fox would have been horrified at the notion that his refusal of a ventilator constituted suicide. As both Eichner and Cruzan make clear, the right at stake in these cases is the right to refuse treatment (even if refusal results in death), and there is no legal requirement that a person be either terminally ill or in pain to exercise this right. Americans have never been obligated to accept any or all man- ner of medical treatment available to prolong life; the essence of the legal right at stake is the right to be free from unwanted bodily invasions.

Even more striking is the court's second assertion, which is based on its acceptance of Justice Antonin Scalia's strange concurring opinion in the Cruzan case (an opinion that no other justice on the Supreme Court joined). Scalia argued that refusals of treatment that result in death are all suicides, and that any notion that the patient dies a "natural" death from the underlying disease is nonsense. ${ }^{4}$ The Second Circuit Court adopted Justice Scalia's position, concluding that death after the removal of a ventilator is "not natural in any sense"; rather, it brings about "death through asphyxiation." 2 Likewise, the Second Circuit Court stated that the removal of artificially delivered fluids and nutrition causes "death by starvation . . . or dehydration." In the court's words, "The ending of life by these means is nothing more nor less than assisted suicide." 2 Because it considered both refusing treatment and taking lethal drugs as equally constituting suicide, the Second Circuit Court concluded that giving citizens equal protection under the law means that the state must treat both acts in the same manner. The court argued that because doctors are permitted to "assist" patients being sustained by various life-support mechanisms to commit suicide by removing them, patients who do not need these medical interventions to continue to live should also be entitled to the assistance of a physician in committing suicide.

As to the state's possible interest in distinguishing between these acts, the court concluded that the state has no interest "in requiring the prolongation of a life that is all but ended." 2 The court continued, "What business is it of the state to require the continuation of agony when the result is imminent and inevitable?" The court did not believe it was giving physicians a new license to kill, since, it believed, "physicians do not fulfill the role of 'killer' by prescribing drugs to hasten death any more than they do by disconnecting life support systems." ${ }^{2}$ The court did, however, specifically reject euthanasia, distinguishing it from assisted suicide: "In euthanasia one causes the death of another by direct and intentional acts. ... Euthanasia falls within the definition of murder in New York." 2

\section{DISTINGUISHING GOOD SUICIDES FROM BAD}

Because avoiding the slippery slope is the chief state interest in prohibiting physician-assisted suicide, the ability to distinguish objectively between good and bad suicides is critical. The opinion of the Ninth Circuit Court overruled a 1995 decision in the same circuit in which Judge John Noonan, writing for a two-to-one panel, had concluded that any attempt to 
define the category of constitutionally protected assisted suicides is "inherently unstable," so that any right to assisted suicide would ultimately have to be available to all adults. ${ }^{6}$ In contrast, the 1996 Ninth Circuit Court's decision issued by a larger panel of 11 judges on that court concluded that doctors can accurately distinguish worthy suicides from unworthy and irrational suicides. In the court's words:

One of the heartaches of suicide is the senseless loss of a life ended prematurely. In the case of a terminally ill adult who ends his life in the final stages of an incurable and painful degenerative disease, in order to avoid debilitating pain and a humiliating death, the decision to commit suicide is not senseless, and death does not come too early. Unlike "the depressed twenty-one year old, the romantically devastated twenty-eight year old, the alcoholic fortyyear-old" . . . a terminally ill competent adult cannot be cured . . . [but] can only be maintained in a debilitated and deteriorating state, unable to enjoy the presence of family or friends. ${ }^{1}$

The court found that frustrating the wishes of such terminally ill patients is "cruel indeed," and quoted Kent's lines from King Lear, spoken immediately after Lear dies, to buttress its argument: "Vex not his ghost: $\mathrm{O}$ ! let him pass; he hates him/That would upon the rack of this tough world/Stretch him out longer." Courts almost never resort to quoting literature, and when they do it, it is usually because they have no legal argument to support their conclusion. I believe that is true here, and the court's misreading of King Lear only serves to emphasize how difficult it is to draw lines or make objective assessments in this area. Thus, the seemingly marginal use of a quotation turns out to be central to understanding the entire opinion. Lear did not die because he was terminally ill or in severe pain. Rather, Lear is much more like the person who dies because of a personal emotional tragedy: in Lear's case, he has just learned that his one faithful and loving daughter, Cordelia, has been murdered, and he has just uttered his famous line over her dead body: "Why should a $\mathrm{dog}$, a horse, a rat, have life,/And thou no breath at all?" Earlier that same day, Lear was prepared to spend many years in prison with Cordelia. But after her murder, Lear dies of a broken heart. There is no suicide and no assistance; instead, to the contemporary reader, Kent acts as Lear's health care agent and exercises Lear's right to refuse treatment by ordering that resuscitation not be attempted. No legal changes are needed to protect the right of someone in Lear's position to refuse treatment.

Taking a line out of context from King Lear parallels the way the court took a line out of context from Casey, ${ }^{3}$ the Supreme Court decision that reaffirmed abortion rights, to use as the basis for the new constitutional right it enunciated. Unlike assisted suicide, abortion is a legally and medically definable act, and unlike the terminally ill, the category of persons to whom the right to abortion applies is objectively verifiable - that is, pregnant women. ${ }^{7}$ Reliance on Cruzan is also problematic. Cruzan involved the right to refuse treatment, not the right to "hasten death." Neither the Missouri Supreme Court nor the U.S. Supreme Court saw a refusal of artificial fluids and nutrition by Nancy Cruzan or her parents on their daughter's behalf as a possible violation of Missouri's law against assisted suicide. ${ }^{8}$

\section{PHYSICIANS AND ASSISTED SUICIDE}

The patients whose cases were presented to these two courts are all sympathetic, and it is not surprising that the courts wanted to help them. Cancer and AIDS often lead to "hard deaths," and patients dying of these two diseases make up the vast majority of patients in hospices, as well as of those who seek the assistance of physicians in committing suicide, ${ }^{10}$ probably because the final stages of these illnesses are relatively predictable. What is surprising is that the courts failed to acknowledge explicitly that it has never been illegal to prescribe pain medication that competent terminally ill patients might use to commit suicide, as long as the physicians' intent is to foster the patients' well-being by giving them more control over their lives and the drugs have independent legitimate medical uses. ${ }^{11}$ Such prescription can legitimately be seen as suicide prevention rather than assistance in suicide. Neither court could point to even one case of a physician ever being criminally prosecuted for the conduct they approve of, and both courts would have been on much stronger ground if they had simply acknowledged that intent matters in criminal law and that prescriptions under these very limited circumstances are not assisted suicide by definition. ${ }^{11,12}$

In this regard, it should be noted that the Ninth Circuit Court's restatement of the principle of the double effect, which treats pain relief and death as equally intended, is false: the principle is that treating the patients' pain is acceptable even if the treatment hastens death (which it will, of course, not always do). Providing medication to control pain has always been a legitimate and lawful medical act, even if death or suicide is risked. ${ }^{11,12}$ There is a difference between an intended result and an unintended but accepted consequence. Thus, no physician should conclude on the basis of the opinion of the Ninth Circuit Court that providing pain medication that increases the risk of death is either assistance in suicide or homicide. As one of the dissenting judges in the Ninth Circuit Court's opinion, Robert Beezer, properly notes, when General Dwight D. Eisenhower ordered American troops to the beaches in Normandy, he knew he was sending many to certain death, but his purpose was to liberate Europe from the Nazis. Judge Beezer continued, “The majority's theory of ethics would imply that this purpose was 
legally and ethically indistinguishable from a purpose of killing American soldiers."

I find it impossible to accept either court's logic about the cause of death after refusal of treatment. If one accepts that Nancy Cruzan "died of starvation" and not from the vegetative condition that made continued artificial feeding necessary for her survival, one would also have to accept the conclusion that when physicians stop attempted cardiopulmonary resuscitation on a patient in cardiac arrest, what kills the patient is not the arrest but rather the physician who intentionally stops compressing the heart. Since the failure to perform cardiopulmonary resuscitation always "hastens death," under each court's logic, patients who refuse cardiopulmonary resuscitation would always be committing suicide (and doctors who write do-not-resuscitate orders would always be assisting suicide). The failure to distinguish real causes of death from various medical tools and techniques that may temporarily substitute for particular bodily functions is fatal to the logic of both of these opinions.

This logical failure also helps explain why neither court could define the right they had discovered or persuasively limit its exercise to cases involving prescriptions written by physicians for competent, terminally ill patients, limitations that have no basis in constitutional law. ${ }^{13}$ The Cruzan and Eichner decisions, after all, support the proposition that the right to refuse treatment is not lost by incompetence but can be exercised in advance by means of a living will or the designation of a health care proxy, and also that an adult need not be terminally ill to refuse treatment. Of course, one cannot commit suicide by proxy. On the other hand, nothing in the logic of these opinions would prohibit physicians from actually injecting lethal doses into patients who met their other criteria and who were unable to commit suicide themselves, although the Second Circuit Court explicitly prohibited this. The Ninth Circuit Court (but not the Second) also explicitly protected family and friends working under the direction of a physician but never explained why either a physician or a prescription drug is constitutionally required. For example, neither court suggested any reason why a physician could not recommend suicide by gun and instruct a patient or family member about where to aim it before the patient pulled the trigger. Since both courts admitted that there is no constitutional definition of terminal illness, the group of covered patients may encompass many with years to live (like Lear) whose lives no longer bring them joy or happiness, and certainly seems to include patients with early HIV infection, Alzheimer's disease, or cancer. To the extent that states have an interest in protecting these persons from physicians who might encourage suicide for reasons other than unrelievable pain or suf- fering at the end of life, these opinions cannot prevent a slide down the slippery slope.

\section{STATE REGULATIONS}

Perhaps recognizing this weakness in their analyses, both courts called for states to regulate physician-assisted suicide, and the Ninth Circuit Court seemed to approve of Oregon Ballot Measure 16, which provides legal immunity to physicians who follow certain procedures when prescribing lethal drugs to terminally ill patients with the intent that they use them to commit suicide. ${ }^{1,14}$ State regulations requiring such protections as second opinions and reporting would, however, take decision making away from doctors and their patients. ${ }^{7}$ Moreover, if one agrees with the Second Circuit Court's analysis of equal protection, the state is permitted to adopt the same or substantially similar regulations for refusals of treatment that "hasten death" as for physician-assisted suicide. If states adopt such regulations, the hardwon rights that the great majority of patients can and do now exercise to refuse medical treatments are put at risk, since mandatory procedural safeguards can actually frustrate rather than foster the selfdetermination of patients. ${ }^{15}$

The opinions can also be read as undercutting all laws relating to schedule I drugs, as well as regulation of medical experimentation, at least with regard to patients near the end of life. If laws against assisted suicide are unconstitutional because they deprive terminally ill patients of relief from suffering, how can laws that restrict their access to heroin or LSD be constitutional? ${ }^{11}$ Contrary to the actions of these courts, the Supreme Court has previously and unanimously endorsed the view of the Food and Drug Administration that drug laws that require demonstrated safety and efficacy forbid everyone, including the terminally ill, to obtain unapproved drugs. ${ }^{16}$

The opinions of the two appeals courts have garnered much editorial support in the press because they seem to expand patients' autonomy by giving them another choice. In fact, however, by equating the refusal of treatment with suicide, the opinions may actually reduce patients' rights by encouraging state governments to regulate treatment refusals that might "hasten death." For those who believe that when physicians honor treatment refusals they are routinely engaged in assisted suicide and homicide, these opinions mark an advance in protection for $\mathrm{pa}^{-}$ tients - but at the cost of taking decision making away from doctors and their patients, and entangling both in even more public and private bureaucracy and scrutiny. Where the court sees only doctors, patients, and the criminal law, physicians know that contemporary medicine is much more complex, with the real power shifting rapidly from physicians to health plans. In this context, both physicians and patients need medical ethics (including informed 
consent and the principle of the double effect) to mean more than just immunity from criminal prosecution.

\section{CONCLUSIONS}

By ignoring the past two decades of jurisprudence concerning the right to refuse treatment (including the rulings by state supreme courts that explicitly hold that refusals of treatment are neither suicide nor homicide), ${ }^{17-19}$ and by failing to make such basic distinctions as those between the right to refuse treatment and the right to die, between suicide and assisted suicide, between law and ethics, and between ends and means, these courts virtually guarantee that their decisions will not be the last word on the subject. The U.S. Supreme Court has not yet decided whether it will hear the appeals of these decisions. Since states have a legitimate interest in protecting all citizens, especially terminally ill and vulnerable citizens, it seems almost certain that the Supreme Court will ultimately uphold state laws that criminalize assisted suicide. ${ }^{13,20}$ Because of its current stand on states' rights, the Court is also likely to permit states to decriminalize physician-assisted suicide if they wish. ${ }^{21}$

There are real problems with the way patients die under physicians' care, and these rulings are important demonstrations of how a large number of judges view dying at the hands of modern medicine. The SUPPORT study, for example, found that the families of 50 percent of a sample of patients who died in the hospital believed that the patients "experienced moderate or severe pain at least half the time during their last 3 days of life." 22 On the other hand, a survey of patients with cancer published after these court opinions were written found that those who had seriously discussed suicide or euthanasia or who hoarded drugs were more likely to be depressed or have poor physical function than to be in serious pain. ${ }^{23}$ Obviously we must understand the patients' problems before we can be sure that our solution will do more good than harm.

Shakespeare changed the traditional ending of the legend on which he based his play to have both Lear and Cordelia die, rather than to have Lear restored to his throne and all live essentially happily ever after. Shakespeare's ending fits well with our postmodern intimations of disaster and apocalypse, just as assisted suicide seems a reasonable way out of our inability to control the decay of our bodies. Nonetheless, the more appropriate lines from King Lear in this context may be the questions of Kent and Edgar near the end of the play: "Is this the promised end?/ Or image of that horror?"

\section{REFERENCES}

1. Compassion in Dying v. Washington, 79 F.3d 790 (9th Cir. 1996).

2. Quill v. Vacco, 80 F.3d 716 (2d Cir. 1996).

3. Planned Parenthood v. Casey, 505 U.S. 833 (1992)

4. Cruzan v. Director, Missouri Dept. of Health, 497 U.S. 261 (1990).

5. Matter of Eichner, 52 N.Y. 2d 363 (1981).

6. Compassion in Dying v. Washington, 49 F.3d 586 (9th Cir. 1995).

7. Callahan D, White $M$. The legalization of physician-assisted suicide: creating a regulatory Potemkin village. 30 U Richmond Law Rev 1996;30:183.

8. Annas GJ. Nancy Cruzan and the right to die. N Engl J Med 1990;323: 670-3.

9. Sontag S. AIDS and its metaphors. New York: Doubleday, 1988. 10. Preston T, Mero R. Observations concerning terminally ill patients who choose suicide. J Pharm Care Pain Symptom Control 1996;4:183-92. 11. Annas GJ. Death by prescription - the Oregon Initiative. N Engl J Med 1994;331:1240-3.

12. Cantor NL, Thomas GC. Pain relief, acceleration of death, and criminal law. Kennedy Inst Ethics J 1996;6:107-27.

13. Kamisar Y. Against assisted suicide-even a very limited form. U Detroit Mercy Law Rev 1995;72:735-69.

14. Lee v. Oregon, 891 F. Supp. 1429 (D. Or. 1995).

15. Wolf SM. Holding the line on euthanasia. Hastings Cent Rep 1989; 19(1):Suppl:13-15.

16. U.S. v. Rutherford, 442 U.S. 544 (1979).

17. In re Quinlan, 70 N.J. 10, 355 A.2d 647 (1976).

18. In re Fiori, 673 A.2d 905 (Pa. 1996).

19. Glantz LH. Withholding and withdrawing treatment: the role of the criminal law. Law Med Health Care 1987-88;15:231-41.

20. When death is sought: assisted suicide and euthanasia in the medical context. New York: State Task Force on Life and the Law, 1994.

21. Baron $\mathrm{CH}$, Bergstresser $\mathrm{C}$, Brock DW, et al. A model state act to authorize and regulate physician-assisted suicide. Harvard J Legis 1996;33:134 .

22. The SUPPORT Principal Investigators, A controlled trial to improve care for seriously ill hospitalized patients: the Study to Understand Prognoses and Preferences for Outcomes and Risks of Treatments. JAMA 1995; 274:1591-8

23. Emanuel EJ, Fairclough DL, Daniels ER, Clarridge BR. Euthanasia and physician-assisted suicide: attitudes and experiences of oncology patients, oncologists, and the public. Lancet 1996;347:1805-10.

(C)1996, Massachusetts Medical Society. 